of such regions of depression as the valleys of the Rhone and Rhine, the low-lying region of Hungary, and the plain of Poland.

News of the African traveller, Herr Gottlob Ad. Krause, has been received at Berlin through the missionary Steiner from Christiansborg on the Gold Coast. On April 16, Herr Krause arrived at Salaga, north of the Appanti kingdom; proceeding in a northerly direction he succeeded in reaching the vicinity of Timbuctoo. At present, most likely, he has arrived at the Togo coast.

\section{THE PROGRESS OF GEOGRAPHY.}

$A \mathrm{~T}$ the anniversary meeting of the Royal Geographical Society, held on May 23, 1887, General R. Strachey, the Vice-President, delivered an address, from which we take the following extracts :-

The attention of geographers during the year, as far as regards Africa, has been chiefly directed to the basin of the Congo, where many explorers, of various nationalities, have been employed in exploring and surveying the numerous streams which combine to make the Congo one of the greatest fluvial systems of the world. Other explorers have been engaged in the same region in examining into its economical and prospective commercial resources, but at present without definite results. An excellent summary of the geographical work done in the Congo region up to the middle of last year was given to the Society in this hall, in June last, by Sir Francis de Winton, who had then recently returned from his two years' administration of the country. The most important of the new explorations he described was that of Lieut. Wissmann and his party, who had embarked on the upper waters of the Kassai River, near the part made known to us by Livingstone and Cameron, and navigated it to its junction with the Congo. Since then Dr. Wolff, one of Wissmann's companions, has explored the Sankuru, a large northern tributary of the Kassai, and found it navigable for a long distance. One result of this latter exploration is to show that another navigable river of the far interior, the Lomami, enters the Sankuru from the northeast, and that it is a distinct river from the Lomami of Cameron, recently ascended by Grenfell, which enters the Congo near Stanley Falls.

The direction which the Kassai takes-in a Iong curve, from south-east to west-north-west-causes it to be the recipient of nearly all the drainage of the southern half of the Congo basin, and near its junction with the main stream it adds to its volume the waters of another great tributary, the Quango, besides the Mfini from a chain of great lakes further north. The united waters are poured into the Congo through the Kwa, which, according to Mr. Grenfell's measurement, is contracted in its passage through a range of low hills, and at its mouth is only 700 yards wide (a little higher up only 450 yards); the depth of the swiftly flowing stream Mr. Grenfell was unable to ascertain, as no bottom was touched with a line 120 feet long.

The prospective value to the Congo State of the Kassai, with its immense mileage of navigable waters flowing through fertile plains, is acknowledged on all hands. Already stations have been founded on its banks, and Portuguese traders are choosing the newly-discovered river route in preference to their old in land road into the interior from Loanda. It has been during the past few months repeatedly reascended by river steamers, once by Sir Francis de Winton himself.

Equal in importance and extent have been the exploration and surveys along the main river and many of its tributaries carried out by Mr. Grenfell. The chief of these explorations were noticed by the Marquis of Lorne in the Address of last year; and a brief general account of his surveys was given, together with a reduction of his admirable series of river charts, in the October number of our Proceedings. Since then Mr. Grenfell has added to his achievements the as ent of the unknown portion of the Quango between its junction with the Kassai (or Kwa) and the Falls of Kikunji, which latter was the farthest point, coming down river, reached by a former traveller, Von Mechow.

Other considerable additions have been made to our knowledge of the Congo region, by Lieuts. Kund and Tappenbeck, members of a scientific Expedition sent out in 1884 by the German African Association. These two courageous travellers, instead of following the courses of the rivers like others, and gleaning information only of the country and people along the banks, struck across the country, first from Stanley Pool to the south, and thence towards the east, crossing in succession all the southern tributaries, from the Quango inclusive to the Lukenye, beyond the Kassaj; a toilsome and dangerous march of about 600 miles. Another member of the same Expedition. Dr. Buittner, made also a land journey, of less extent, but not less interest. Starting from San Salvador, the old capital of the Congo, he travelled eastward and crossed the Quango, reaching the capital of a Negro potentate named Kasongo, whence he struck northward to the main Congo above Stanley Pool. Much valuable information regarding the configuration of the country and the ethnology and products of the interior was obtained on these two journeys. We learn, for example, that the whole western section, to a distance some 400 miles inland, is a hilly country cut up by deep valleys, to which succeeds, further inland, a wide stretch of undulating plains, wooded only along the courses of streams, and that it is only when the eastern side of the Kassai is reached that continuous tropical forest is met with.

North of the Congo the French have been active both in completing the pioneer exploration of their new possessions and in laying down with scientific precision large tracts of country imperfectly known. The most important work of the latter kind is that of Capt. Rouvier, the representative of France on the joint Commission for laying down the boundary between the Congo State and the French possessions. This accomplished surveyor fixed numerous positions by a long series of observations both for longitude and latitude, and his Report, which will be accompanied by an atlas of thirty-eight maps on various scales, will form a solid contribution to our geographical knowledge of the region. An important pioneer exploration, about the same time, was made by $M$. Jacques de Brazza, brother of the eminent traveller, to the north and east of the French sta. tions on the River Ogowé, undertaken soon after Mr. Grenfell's discovery of the magnitude of the Mobangi, and apparently with the object of ascertaining whether that great river flowed within the French boundary as fixed at the Berlin Conference. After a journey of a month's duration through dense forests, $M$. de Brazza emerged on an open plain, through which flowed, not the Mobangi, but the Sekoli, an independent tributary of the Congo lying far to the westward. After a fruitless attempt had been made to penetrate beyond this river, his party built canoes and descended the Sekoli to its mouth. It has been recently announced that by arbitration the French boundary has been extended a little farther to the east than fixed by the Berlin Conference, so as to include the right bank of the Mobangi. A complete and very useful résumé of all the geographical work accomplished by recent French explorers in the Ogowé-Congo region, by Major de Lannoy de Bissy, was contributed to our Proceedings for December last, illustrated by a map reduced from the French surveys.

Public interest has recently been directed towards the region north of the Congo, and the practicable routes it may offer to the Niam-Niam countries and the Egyptian Soudan, in consequence of the despatch of the Expedition under Mr. Stanley, for the relief and rescue of Emin Bey, which has adopted the Congo route to the Upper Nile in preference to the more direct and shorter route inland from Zanzibar. A paper giving a résumé of all published information regarding this region was recently read in this hall by our accomplished young colleague, Mr. J. T. Wills. Since then, you have had before you the greatest of all travellers in this little-known region, Dr. Junker, and heard his own account of his six years' explorations. The wide open plain country lying between the Congo and the Nile, which Dr. Junker described to us, is watered by numerous streams, the chief of which, the Welle-Makua, flows westerly in the direction of the Upper Mobangi, and, judging from Dr. Junker's maps, it is difficult to dispute his conclusion, in which Mr. Wills agrees, that the two rivers are the same. Other geographers believe that the Welle-Makua belongs to the Shari system and flows into Lake Chad. The alternative offers one of those problems in which speculative geographers seem to delight ; but in this case it will not be long before a solution is arrived at in the only satisfactory way-namely, by actual exploration. Meantime we learn, by the latest news from the Congo, that Mr. Stanley has chosen to adopt a somewhat more direct route to Emin Pasha than that first proposed-namely, from the Congo near Stanley Falls by land to the shores of the Albert Nyanza. 
Two more journeys across the continent have been brought to a successful conclusion during the past year. One by M. Gleerup, a Swedish of ficer, formerly in the service of the Congo State, who crossed from Stanley Falls to Zanzibar, and the other by the experienced traveller and geologist. Dr. Oscar Lenz, who undertook, in 1885, an expedition for the purpose of reaching Dr. Junker and Emin Pasha viâ the Congo. Reaching Stanley Falls in February 1886, Dr. Lenz was unable to obtain men from the Arab traders there to accompany him on the march through the unknown country between that point and the Upper Nile, and proceeded to Ujiji in the hope of meeting with better success there, and advancing northwards along the eastern side of Lake Tanganyila. The disturbed state of the country and the excitement in Uganda made this impossible, and he took the Tanganyika and Nyassa route to the Indian Ocean, emerging at the Portuguese settlement of Quillimane.

Further south, Dr. Hans Schinz, a learned botanist and ethnologist, has been exploring with fruitful results the region between the Kunene and Lake Ngami.

On the eastern side of the continent our Society is espacially interested in the expedition of Mr. J. T. Last, who was commissioned by us in the summer of 1885 to proceed to the region between the Rovuma and the Zambesi, and follow up the work of Mr. O'Neill by exploring the Namuli Hills and the Lukugu Valley. We hear by recent telegram of his safe arrival at Zanzibar, and may shortly expect him home to give us in person an account of hi ; journey. The letters which we have received from him from time to time have informed us that he has carried out his programme, though he found the summit of the Namuli Hills inaccessible, and, in addition, traversed the whole region a second time, striking into the interior from Quillimane, and emerging at Ibo on the Mozambique coast.

Count Pfeil, one of the most active of the pioneers in the newly-acquired German Protectorate of Eastern Tropical Africa, publisbed last year an account of his two journeys in Khutu and in the neighbouring region, a country previously known to us only through Thonson's expedition to the Central African Lakes. Some additions to our knowledge of the geography of this part of the Africa.l interior have resulted from Count Pfeil's labours, the most interesting of which is the discovery of the main stream of the Ulanga, or upper course of the Rufigi, a river which this explorer claims to be of some importance, and which he navigated in a boat for upwards of 150 miles.

The unsuccessful attempt of the experiencel African traveller Dr. Fischer to carry succour to Dr. Junker in I $385-86$, a mission with which he was charged by that traveller's family, would have excited great interest in the earlier days-not long past-of Central African travel. The route he took led for several hundred miles through a totally unexplored country, namely, from the Pangani westward across the region which still remains a great blank on our maps to the caravan route between Unyanyembe and Victoria Nyanza. He reached the southern shores of the Victoria in January 1885, but found it impossible to obtain leave to pass through the territory of the fanatical king of Uganda. Turning backward he made a valiant attempt to reach the Upper Nile by the eastern side of the great lake, but his supplies failed him by the time he arrived at Lake Bahringo, and he returned with a sorrowful heart to the coast. He did not long survive the fatigues of this arduous journey, but died soon after his return to Europe, in November last.

In the continent of Asia the most important addition to our accurate geographical knowledge of the interior is no doubt that gained by the joint Russian and British Commission, which has been engaged on the survey of the northern frontier of Afghanistan from the borders of Persia to the Upper Oxus, but pending the diplomatic settlement of disputed points this information has $n$ t been made public, though it will doubtless soon become available. A brief note of a portion of this work, describing surveys made by Capt. Maitland and Talbot, between the Hari-rud and Bamian, connecting Herat with the last-named place, and also with points north of the Oxus, and the neighbourhood of Kunduz, has appeared in our Proceedings. The total area surveyed amounts to about 120,000 square miles, mapped on the scale of $\frac{1}{4}$ inch to the mile, in 60 sheets. These brilliant results are believed to be unique in the annals of surveying. The chief of the British topographical staff, by whom these surveys were undertaken, was Colonel Holditch, to whom one of the Gold Medals has now been awarded, in recognition of the valuable services to geography rendered by him in this and other similar expeditions.
Much valuable geographical work has also been accomplished by Mr. Ney Elias, the Gold Medallist in 1873, who was despatched from Ladakh on a mission to Chinese Turkistan, and diverging westward at Yengi Hissar, traversed the Pamir Plateau for a distance of 360 miles, to the Khanat of Shignan. The details of this $\mathrm{j}$ urney have not yet been made known by the Indian authorities, but Sir Henry Rawlinson ha; communicated to our Proceedings a note in which he points out that his former suggestion that this route, first brought to notice by Major Trotter, was probably that by which caravans of Rome passed from Bactria, and had been used as a military road in comparatively modern times, is confirmed by the additional light now thrown on the subject; and he identifies the lake Rang-Kul, visited and described by Mr. Llias, as the famous Dragon Lake of Buddhist cosmogony, and as answering very closely to the description given by the Chinese traveller Hwang-tsang in the seventh century.

Mr. A. D. Carey, a gentleman in the Indian Civil Service, has in a most enterprising manner devoted a period of leave of a'ssence to a very remarkable journey in Lastern Turkistan and Tibet, and has traversed a large part of those central regions which have lately been made known by General Prejevalsky, and of which a brief résumé was given in the last Presidential Address. Accompanied by Mr. Dalgleish, an enterprising trader, who had previously visited Eastern Turkistan, he started from Ladakh in the summer of 1885 , taking a route which had never before been trodden by a European, from Leh eastward across the high Tibetan plateau, and descending to Kiria by an extremely difficult and rugged defile via $a$ Polu. After a short stay here, he traversed the desert northward, along the course of the Khotan River, and arriving at the Tarim, crossed that river to Shah-yar and Kuchar. At the end of the year he tracked the Tarim to Lake Lob, and proceeded thence in a southward direction to the foot of the great escarpment which in this meridian forms the northern limit of the Tibetan highlands, where he wintered, and made a fresh start across the Altyn Tagh in the spring of 1886 . No news having been received of him for many months, his friends had begun to fear for his safety, but all anxiety has been set at rest by recent telegrams from India announcing his safe arrival at Ladakh at the end of the winter. Considering that Mr. Carey travelled without escort and unarmed, and that his journey has been performed on slender means through vast unknown tracts peopled by tribes supposed to be of hostile and fanatical temper, his exploit is one of the most remarkable in the recent annals of adventurous travel.

Northwards of Khatmandu, the capital of Nepal, about 400 miles of entirely new traverse in Nepal and Tibet has been contributed by a native explorer, surnamed $M-H$, , besides a confirmation of the details of a hundred miles of ground previously travelled over. It is regrett ed that the explorer brought back no determinations of heights, which would have been most interesting, for he crossed the main ridge of the Himalayas by one of the highest passes (the Pangu-la), and approached within I 5 miles of Mount Everest. Another native surveyor, $\mathrm{R}-\mathrm{N}$., who acc. mpanied Colonel Tanner in his explorations on the Tibetan border in the autumn of 1884 , was despatched across Bhutan and the mountains to the east to reach Gyala Sindong, the lowest point yet reached on the Sanpo, and, starting from the left bank of the river, to find his way back to India by any practicable route, without recrossing the river. The object was to set at rest the vexed question of the connexion between the Brahmaputra and the Sanpo on the one hand, and the Irawadi on the other. The explorer met with bad luck at the outset, from the fact of there being hostility between Tibet and Bhutan, a state of things which had closed all the passes into Tibet. He therefore had to find his way back to India down the Hachhu and Wongchu Rivers to Baxa, having been detained and kept under surveillance for ten days by the jongpon of Chukhajong. His next attempt was made from Dewangiri, whence he proceeded by a pretty direct route to the Monlakachung Pass, and thence to the vicinity of Seh, a very large monastery on the Lhobra River, the position of which had been previously ob. tained from the north by Lama U-G.'s traverse of $I 883$. Here, in consequence of the rumours regarding the advance of the Tibet Mission from the south, and of a party of Russians from the north, the officials absolutely stopped his further pro. gress, and kept him in custody for nine days, and then conveyed his party under escort to Seh. From here he escaped with his party by night, and, keeping away from the beaten tracks, found his way to Menchuna (lat. $28^{\circ} \mathrm{N}$., long. $92^{\circ} \mathrm{E}$.), and 
thence, viâ Tawang, to Odalguri, along the route formerly traversed by Pundit Nain Singh. His work furnishes about 280 miles of new route survey, and throws light on the general geography of Bhutan, besides forming a connexion with the work of Pemberton ( 1838 ) from the south, and of the Pundit and the Lama from the north.

Another journey carried out by three English gentlemen through the heart of Manchuria, from south to north from the shores of the Yellow Sea, and from west to east to the Russian settlement of Vladivostock on the Pacific coast, also calls for notice. The party consisted of Mr. H. E. M. James, of the Indian Civil Service; Mr. F. E. Younghusband, of the King's Dragoon Guards ; and Mr. H. Fulford, of the Chinese Consular Service. We have received at present brief accounts only of this meritorious achievement; but they are sufficient to show that the travellers made excellent use of their opportunities of gaining accurate information regarding the country, its inhabitants, and products. One of their objects was to ascend the Pei-shan or White Mountain, the highest mountain in the country, which they accomplished, and fixed its altitude by boiling-point and aneroid at 7525 feet, the estimates previously given in books making it 10,000 or $\mathbf{1 2 , 0 0 0}$ feet. A very good map of their route was plotted and a copy obligingly communicated to the Society. Mr. James has just arrived in England, and we may hope to have an early opportunity of hearing from his own lips an account of his journey.

The recent addition of Upper Burmah to the territories administered by the Viceroy of India, makes it certain that before long the various questions that have till now puzzled geographers in relation to the course of the rivers that rise in Tibet and flow from that country, will be finally cleared up, and a staff of surveyors under Capt. Hobday is already at work in this country. The sources of the Brahmaputra have already been ciearly designated; but doubts still surround the origins of the Irawadi, which actual surveys will, it is to be hoped, before long dispel.

The expectations entertained of the opening up of the still unknown interior of New Guinea, from the southern or British portion of the island, by the expedition of Mr. H. O. Forbes, have, unfortunately, not been fulfilled. Mr. Forbes spent the rainy season in the early part of 1886 in camp, at a short distance inland from Port Moresby, profiting by the enforced inactivity, in cultivating friendly relations with the tribes, learning the Ianguages, and making botanical collections. The remainder of his resources during these months was exhausted, and when at the commencement of the fine season, in April, he made a bold attempt with the great advantage of the companionship of the Rev. J. Chalmers, to reach the summit of the Owen Stanley Range, the term of service of his Amboynese escort had expired, and he could do no more than make a few observations in the rugged country at the foot of the mountains, 75 miles distant from the coast. Since then, he has not been enabled to renew his explorations. We learn, however, that the Government of Victoria has taken the matter in hand, and that a well-equipped Expedition is in preparation for the exploration of the interior, the leadership of which is to be offered to Mr. Chalmers, whose account of his varied explorations along the south-eastern coastregion, given at one of our evening meetings during this session, will be fresh in your memories. The great influence which this experienced missionary pioneer has obtained over the natives, and his knowledge of their habits, inspire us with great hopes in the success of this enterprise, which so much depends on the willingness and fidelity of native followers. Several minor excursions have since been made by various travellers, but very little has been added to our knowledge of the southern portion of the island. Capt. Everill's larger Expedition, fitted out in New South Wales, succeeded in ascending the Fly River and penetrating for some distance up an eastern arm or tributary named the Strickland, which is said to flow in the rear of the range of coast hills, but the map of the parts explored has not yet reached us.

In German New Guinea the discovery of the important river, named after the Empress Augusta, was confirmed by Capt. Dallmann, who in April $\mathbf{r} 886$ ascended it in a small steamer for a distance of 40 miles, and it has since been further navigated by Admiral Von Schleinitz and Dr. Schrader in the steamer Otilie, which reached a distance of 224 miles from the mouth, the ship's steam launch ascending 112 miles further, finding still sufficient water, but being obliged to return for want of fuel.
The progress made in the great continent of America, which still offers wide fields for the explorer, and still wider and more productive fields for the physical geographer, remains now to be briefly noticed. As a contribution to physical geography, Mr. John Ball's recently published volume on his voyage round South America and various short journeys inland at various points, merits special mention. It is a model of what serious books of travel that aim at conveying accurate knowledge of the countries visited ought to be.

In Central America, our colleague, Mr. A. P. Maudslay, continues his explorations of the sites and his studies of ruined cities, having returned to $\mathrm{Yucatan}$ and Guatemala after reading to us in June last the results of his second and third visits to Central America. His work has great geographical and ethnological as well as antiquarian interest, and his excavations at Copan show that the ruins are those of a city, and not simply of a group of sacred edifices, and that the course of the Copan River has changed somewhat since the remote time at which the massive walls of the buildings had been erected. $\mathrm{He}$ believes that he has good ground for concluding that Copan and other cities were abandoned before the Spanish discovery of America in I 492 .

Lastly, there remains to notice an admirable labour of exploration in the interior of Brazil by a private scientific Expedition consisting of Dr. Karl von den Steinen, Herr W. von den Steinen, and Dr. Otto Claus. These gentlemen set themselves the task of exploring the course of the Xingu, one of the great southern tributaries of the Amazons. The work was accomplished in 1884 , but the first detailed accounts of it were published only in May and June last year. The party proceeded in the first place overland to Cuyaba in the far interior, and, organizing there their caravan, proceeded to the sources of the great river, and descending along the banks of the principal stream, through wild Indian territory, to the point where it becomes navigable, built bark canoes, and paddled down the river a distance of about 1000 miles to its junction with the Amazons. Throughnut the journey, in addition to the geographical survey, physical, biological, and anthropological observations were made with the usual thoroughness of German travellers.

It will not be out of place at the present time, when our countrymen are celebrating in all parts of the globe the fiftieth year of the reign of Her Majesty Queen Victoria, to look back on the progress that has been made in geographical knowledge since the commencement of that reign, which dates seven years after the foundation of our Society. The time at my disposal will only admit of an extremely brief review, and I would refer you for more ample details to the valuable memoir drawn up by our esteemed Secretary, Mr. Clements Markham, and published by the Society a few years back, under the title of "Fifty Years" Work of the Royal Geographical Society." A comparison of the maps of fifty years ago with those of the present day shows how great have been the additions made to our knowledge during this period. Foremost, in this respect, must be placed the maps of Africa, the interior of which has been transformed from an almost complete blank, containing little more than hypothetical geographical features derived from the reports of native traders some of which had been handed down to us from the time of Ptolemy, to trustworthy representations, based on precise clata, of a vast system of rivers, lakes, and mountains, the existence of which had been wholly unknown to the civilized world. This continent has at length been traversed and re traversed in all directions, and what remains unknown, consists of details needed to fill in well-ascertained large outlines, rather than essential features still to be discovered. Closely following the progress of geographical research, some of the latest fruits of which it has been my agreeable duty to recognize to-day, when presenting one of the Gold Medals of the Society to Mr. Grenfell, the advance of commercial enterprise is already carrying the pioneers of civilization, recruited from all the principal States of Europe, into the heart of what may without exaggeration be called a newly-found quarter of the globe.

The additions to our knowledge of the great insular continent of Australia have been hardly less remarkable; and the difficulties that have been overcome, and the enterprise and endurance displayed in the investigation of its geography, have never been surpassed in the history of the earth's exploration. Here, too, hand in hand with the advance of geographical knowledge, the domain of civilization has been extended, and the Australian colonies have started into existence fully armed as it were from 
their birth for the battle of national life. Our fellow-subjects in those distant countries have already displayed their complete fitness to undertake the task of further geographical investigation in that quarter, and to them we may now confidently leave it, assuring them of the continued sympathy and interest with which their labours will be regarded by this Society.

During the period to which I am referring, much also has been done to add to our knowledge of the formerly little understood geography of Central Asia. The Russian geographers on the north, and our own surveyors on the south, have now almost entirely cleared away the darkness that shrouded this part of the earth's surface. The limits and the nature of the central plain lying between the mountains of Siberia and of Tibet have been at length satisfactorily ascertained. The long-discussed problem of the true source of the Brahmaputra has been finally solved. The remarkable plateau of Tibet has been crossed in many directions, and important parts of it have been accurately surveyed, so that here also what remains to be done is rather to complete the delineation of details than to enter upon altogether new investigations.

The large geodetic and topographical operations in connexion with the international demarcation of the northern boundary of Afghanistan will supply all that seems still required to complete the maps of Western Asia between the Indus and the Caspian.

Turning to the American continent, we find a measure of progress which, to say the least of it, quite equals that obtained elsewhere. The exploration of the vast tract lying between the valley of the Mississippi and the Pacific has been carried out by the United States Government with a degree of completeness, both in respect to its topographical representation and its physical characteristics, that has probably never been approached elsewhere, and the whole country has thus been thrown open to the enterprise of the energetic citizens of the United States, who have not been slow to possess themselves of its natural wealth.

In British North America, under less favourable conditions for the prosecution of such systematic surveys as those carried out in the territories of the United States, much has still been done, and the recent opening of the railway connecting Columbia on the Pacific with the eastern Canadian States, and the establishment of another through route to Eastern Asia, will doubtless before long lead to the thorough exploration of the countries through which the railway passes.

The Arctic voyages which had been originally commenced with the hope of finding a practically useful north-west passage to Asia, have long ceased to be animated by such an expectation, and their repetition has been undertaken in the cause of geographical exploration alone.

The results of the numerous expeditions undertaken during the last fifty years, combined with those obtained by land journeys directed from British North America, have very completely defined the southern border of the Polar Sea between Behring Strait and Greenland, and have secured the precise delineation of the somewhat complicated system of channels by which the northern border of the American continent is intersected, and of the islands formed by them, along the Arctic circle. In like manner the boundary of this sea has been determined by voyages directed to the north-east along the northern border of Asia.

The highest latitude reached hitherto is rather less than $83 \frac{1}{2}^{\circ} \mathrm{N}$. - that is, within 500 miles of the Pole. The further extension of the exploration of the north of Greenland and of Franz-Josef Land may still be possible, and it is by journeys in this direction that any closer approach to the North Pole will probably be most readily attainable.

I should not omit mention of the memorable voyage to the Antarctic Circle under the most experienced of the Arctic naval commanders of his time, the results of which were of the greatest scientific value, though the difficulties arising from climate that stand in the way of a near approach to the South Pole prevented the Expedition reaching a higher latitude than $78^{\circ} I^{\prime} S$.

Lastly, I may notice the remarkable additions that have been made during this epoch to our knowledge of the ocean, its depths, its temperature, the winds and climates that pre vail over its various portions, its currents, and the life with which it abounds. Much of the knowledge thus acquired has supplied completely new and wholly unexpected data with which to deal in our endeavours to interpret the earth's history, and to understand the phenomena it presents to us.
It has been in connexion with the extension of geographical discovery, both that to which $I$ have thus more specially referred, and other similar explorations to which specific reference has not been possible, that there has been accumulated a great mass of knowledge which has had a most important place among the causes which justify our assigning to this epoch its conspicuous character of deserving to be recorded in the history of the present times as the age of scientific progress. There is no room to doubt that it was only by aid of the accumulation of a knowledge of numerous forms of life from various countries, developed under different conditions, that the remarkable generalizations of Darwin and Wallace as to the origin and distribution of species became possible ; and that in this sense those great conceptions of the signification of the wonderful variety in the forms of animal and vegetable life, and of the remarkable manner in which they are found associated in various parts of the earth, which it has truly been said are worthy of being classed with the sublime discoveries of Newton, may be regarded as consequences of geographical exploration and discovery. In a somewhat similar manner the progress of geology follows that of geography, and the same may be said of almost all the natural sciences.

In some branches of science the student is able to submit his conclusions to the test of experiment, to vary the conditions of his investigation at his pleasure, and to draw his inferences from the varying results under the changed conditions. In the great laboratory of Nature no such control of conditions is within our power. But by suitable variation of our geographical position, we are able to observe the effects that the physical forces of Nature have produced under varied conditions, and it thus becomes possible to some extent to obtain a substitute for the power of direct experiment.

Properly to estimate the relation between geographical conditions and any observed effect, it is obviously necessary to possess a sound knowledge of the physical forces that may be called into operation in producing that effect, and consequently such a knowledge is of essential importance to every geographer.

I shall not detain you to say anything more on the much-discussed subject of geographical education. I desire to point out, however, that, for such reasons as I have briefly indicated, it is hardly possible to over-estimate the value of exact and scientific geographical research, and that this can only be attained by those who have been properly prepared by previous training. Such a training, it is hoped, may be provided by the instruction which it has been the earnest desire of the Society to see imparted at our chief Universities, and which I trust may not only add to the number of our scientific travellers, but serve generally to throw on many other branches of study that light which an intelligent knowledge of geography alone can supply.

\section{UNIVERSITY AND EDUCATIONAL INTELLIGENCE.}

THE following is the list of Scholarships, Prizes, Associateships, \&c., awarded at the Normal School of Science and Royal School of Mines, South Kensington, for the Session r886-87:-

First Year's Scholarships-Samuel B. Asher-Aron, William Tate, James A. Schofield, Savannah J. Speak. Second Year's Scholarships-William Blackmore, Henry Sowerbutts.

Edward Forbes Medal and Prize of Books for Biology-Miss Agnes Calvert. Murchison Medal and Prize of Books for Geology-Thomas H. Holland. Tyndall Prize of Books for Physics, Part I.-James W. Rodger. De la Beche Medal for Mining-John W. Sharwood. Bessemer Medal with Prize of Books from Prof. Roberts-Austen for Metallurgy-John Richards. Hodgkinson Prizes for Chemistry-Ist Prize, Books, John T. Hewitt; 2nd Prize, Book, William E. Hotson. Frank Hatton Prize for Organic Chemistry-John T. Hewitt.

Associateships (Normal School of Science)-Mechanics (Ist Class) : Albert Griffiths, Ernest A. Hamilton-Gordon. Physics (Ist Class) : Arthur T. Simmons. Chemistry (Ist Class): John H. Powell, John T. Hewitt ; (and Class) : William R. Bower, Herbert Anderson, Walter D. Severn, Ernest H. Smith, Frank Belcher. Geology (Ist Class) : Walter G. Ridewood, William F. Hume.

Associateships (Royal School of Mines)-Metallurgy (Ist Class): John Richards, André P. Griffiths, James A. Gilmour, Arthur E. Cattermole, Andrew McWilliam ; (and Class): Sidney Allingham, Hugh Barbour, Arthur M. M. Cooke, 